alternativer. Om noen år vil man kanskje kunne oppleve at det er en alminnelig oppfatning ute blant folk at det offentlige ikke er i stand til å drive sykehus, og at det vil være bedre å privatisere det aller meste. En slik privatisering vil da kunne gå ganske greit, rammeverket er allerede på plass, sykehusbygningene står der de står, og det er ingen mangel på utenlandske aktører som gjerne vil slippe til på det norske markedet. Det mangler bare noen få lovendringer og stortingsvedtak.

Det offentlige vil sannsynligvis beholde noen institusjoner for de lavtlønte og fattige, det vil nok bli ganske mange i den kategorien om noen få år. Disse sykehusene vil ikke bli attraktive arbeidsplasser for norsk helsepersonell, men så lenge vi har EØS-avtalen med fri flyt av arbeidskraft, vil det ikke by på problemer å rekruttere helsepersonell med lavere krav til arbeidsmiljø, rettigheter og lønn.

Mange vil nok mene at dette er reinspikka konspirasjonstenkning, jeg mener at det er et realistisk scenario. Spørsmålet er hva slags helsevesen vi ønsker her til lands, og om politikerne skal få fortsette å overkjøre pasienter og helseprofesjonene i all evighet.

\section{Marit Sandtrø}

marit.sandtro@hist.no
Litteratur

1. Haug C. Alt på ett kort. Tidsskr Nor Legeforen 2012; 132: 2033.

Publisert som rask respons i nettutgaven 13.10. 2012.

\section{RETTELSE}

Skandinavisk stipend til ung norsk thoraxkirurg

Gunn Marit Seberg

Tidsskr Nor Legeforen 2012; 132: 2247

I Tidsskriftet nr. 19/2012, side 2247 skal det ved bildet stå:

Foto Roy Trondsen, Universitetet i Oslo

3. avsnitt i teksten skal begynne slik: Bjørnstad tok medisinsk embetseksamen i Bergen i 1999, ...

Vi beklager feilene, de er rettet i nettutgaven.

Marit Sandtrø (f. 1955) er internasjonal koordinator ved Høgskolen

i Sør-Trøndelag.

Ingen oppgitte interessekonflikter. 